\title{
Using Backup and Restore Automation from Disaster in University Information Systems
}

\author{
Johanes Fernandes Andry \\ Faculty Technology and Design \\ Bunda Mulia University \\ Jl. Lodan Raya No. 2 Ancol, North Jakarta 14430 \\ jandry@bundamulia.ac.id
}

\author{
Honni \\ IEEE Member: 92626876 \\ Faculty Technology and Design, Bunda Mulia University \\ Jl. Lodan Raya No. 2 Ancol, North Jakarta 14430 \\ honni@bundamulia.ac.id
}

\begin{abstract}
For information system users in university, especially for those who work daily and frequently which deals with storing data in the computer, the computer should be aware of sudden "disaster", such as virus, due to system failure. When "disaster" happens, it can hide or even lose the data or files in the computer. Backup is needed to prevent the loss of data when the computer is attacked by "disaster". It is highly recommended for organizations even individuals to do data backups on a regular basis. It is important in order to avoid the loss of important data when the disaster hits. While restore is to bring back the system to a certain point before. This paper proposes an application to automate the process of backup and restore called "SIPINTAR" which ensures that the data is stored properly and safely. The results are useful for helping individuals and organizations to protect their computers from system failure or other "disaster".
\end{abstract}

Keywords - Information Systems; Back up; Restore; Disaster.

\section{INTRODUCTION}

Institutions such as universities from different types (small, medium and large) consider information as one of the most important assets that need to be secured against expanding number of dangers [1]. Online learning method (elearning) is a method which enables the teacher to conduct learning activities wherever and whenever. It has many functions and purposes so that the teacher can get a lot of information to be used in teaching and learning process. Data is important, therefore data storage and its protection is a serious issue which should be considered [2]. In conducting elearning, the teacher also can do operations such as grading, making schedules, announcements about certain rules or about classes, students and teacher data, etc. Most institutions now have more prominent attention to different sorts of business intrusions [3], [4] and they move forward to get ready for congruity of organizations, ensuring businesses are resilient and deploying a fast recovery after an emergency [3], [5].

Data and information on value, scheduling and teaching and learning process is very important, it needs a reliable backup application. Their ultimate objectives are to satisfy stakeholders' needs in addition to keeping in business for as long as they can [3]. Information can be imitated naturally and accurately to numerous areas. Numerous replication calculations duplicate information esteems from the source information thing to its reproductions [6]. Data backup is a necessary requirement for every organization [1]. The first step in understanding disaster recovery is to define and measure it [7].

\section{THEORY}

\section{A. Backup and Restore}

A disaster recovery plan is similar to an insurance policy that provides comprehensive protection from natural disasters, such as earthquakes, surges, sea tempests, and tornadoes. Disaster recovery plans over the years that are typically used by organizations that have computers and data for daily business operations. Recovery planning process is expensive, an alternative is to backup data from your computer and store it in an alternative location [8]. A disaster is anything that can cause a disruption in the normal operation of a business [9], [10]. Nowadays, more people use computers to store important documents, and a variety of other small information that may need to be maintained for a long time. Doing backup data computers is important to keep the document in the long term as well as short term.

\section{B. Information Systems E-Learning}

E-learning can be defined as a learning process created by interaction with digitally delivered content, network-based services and tutoring support E-learning is any technologically mediated learning using computers whether from a distance or in face to face classroom setting, it is a shift from traditional education or training to ICT-based personalized, flexible, individual, self-organized, collaborative learning based on a community of learners, teachers, facilitators, experts [11]. The software was designed and coded to operate within a unique environment of databases, operating systems and hardware. Most of the hardware used proprietary applications programming interface to interface with the learning system [12]. Information System (I.S) is basically concerned with data processing into some information. IS works in every system, which provides information for the managerial activities in university. A framework to change over information from inside and outside sources into data and impart that data in an proper shape, to chiefs at all levels in all capacities to empower them to settle on convenient and compelling choices for arranging, coordinating and controlling 
the exercises for which they are capable. Others, however, give it more limited scope. They see it as a IS e-learning collecting and analyzing data and producing reports. Its purpose is to help managers to solve structured problems [13], [14].

\section{Disaster}

The term disaster or catastrophe owes its starting point to the French word "Desastre" which is a mix of two words "des" meaning terrible and "aster" which means star. In this way the term alludes to 'Awful or Evil star'. The disaster is an event of natural or manmade causes that leads to sudden disruption of normalcy within society, causing injury to life and property, to such an degree that typical social and financial instruments accessible are deficient to reestablish commonality. Debacle is a cataclysmic interruption of life in a general public caused by nature or a man made circumstance [15].

\section{METHOD RESEARCH}

This research consist of two stages following with 8 steps, there are: (1) Preliminary study I, (a) Observations, (b) Literature review, (c) Identification of requirement, (d) Design Information system of backup and restore with SDLC Water fall and (2) Preliminary study II, (d) Observation of real system (e) Testing information system backup and restore for disaster using any conditions (f) Analysis, (g) Conclusions and recommendations. The flowchart of the research is illustrated schematically in Figure. 1.

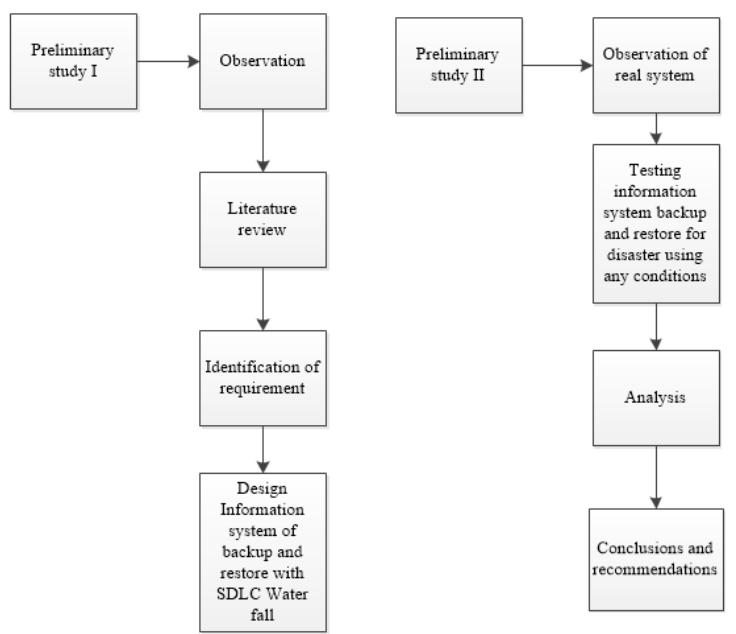

Fig.1. Flowchart of Research

Figure 2 shows SDLC of the waterfall life cycle model (adapted from Balaji and Murugaiyan 2012). The waterfall show was presented by Royce in (1970), particularly with regards to rocket mission programming plan, what's more, is a standout amongst the most well known strategies, and is one of the most popular methods of assessing the evolution of a product or system. Essentially, it is a step-by-step sequential description of the product's life cycle that spans 7 different stages, originally denominated "system requirements, software requirements, analysis, program design, coding, testing and operations". The first premise in which this model is based is that any development process of any software or system starts off by two essential steps: analysis and coding. This is the simplest conceptualization of the model, but is ineffective to understand the product's further development beyond the stage of creation. Therefore, the analysis stage is broken down into two steps - analysis of both system and software requirements, while the coding stage is preceded by program design [16].

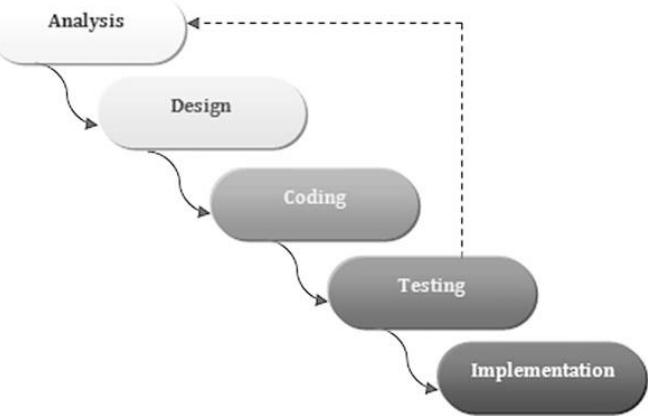

Fig.2. SDLC of the waterfall life cycle model adapted from Balaji and Murugaiyan 2012 [17].

Software engineering research is intended to help improve the practice of software development, so research planning should make provisions for the transition. Software engineering research includes, but is not limited to, experimental research. [13], [18].

\section{Result AND ANALYSIS}

Educational institutions depend upon on-demand data systems, from student records, schedules of subject, announcements to professional research and content, to administrative applications and much more. Most conventional backup methods are outdated and limited in its scope of data protection, as it does not meet the requirements of educational that may have offices in multiple departments and campuses with vital information. Disaster recovery for these institutions implies protection of localized data pertaining to records, exams, and etc.

The development of a IS requires several phases, which have a relation on the activities. The activities include analysis, design, coding \& testing, implementation and maintenance that sometimes referred to as phases. On the phase have elements that provide the framework for manage the project. Waterfall approach was SDLC first model to be utilized broadly in Software Engineering to guarantee achievement of the venture. In "The Waterfall" approach, the whole process of software development is divided into separate phases. Waterfall SDLC demonstrate is a successive programming improvement process in which advance is viewed as streaming progressively downwards (like a waterfall) through a rundown of stages that must be executed keeping in mind the end goal to effectively construct a PC programming. Initially, the Waterfall demonstrate was proposed by Winston W. Royce in 1970 to describe a possible software engineering practice [19], [20].

Software requirements are establishes the expectations for software functionality and identifies which system requirements the software affects. Requirements 
analysis includes determining interaction needed with other applications and databases, performance requirements, user interface requirements, and so on [21]. Requirement of information systems is user both individuals and organizations protected by a system failure or other disaster, which is expected to reduce the cost in the event of damage to files or data on the client computer and can also duplicate data into separate media. Data from such duplication will be used to restore the data in case of damage or loss of data. In analyzing the proposed system for this application is the user can perform backup and restore automatically, at which time the backup files and folders can be setup in the coveted drive. Utilize case is speaks to a noteworthy bit of framework usefulness and on-screen character is a man or framework that gets advantage from and is outer to the subject [22], [23]. Actor in this case is user both individual and institutions, use case are backup, configuration and restore, which user can backup and restore, with configuration whenever, wherever drive of PCs.

Analysis phases are phase to understand and to keep in all the detail of business needs and the processing requirements of the new system. Instruments and procedure for investigation is UML. The Unified Modeling Language (UML) is generally accepted as the de facto standard modeling notation for the analysis and design of the object that oriented on software frameworks [13], [24]. UML is an institutionalized broadly useful displaying dialect in the field of software engineering and programming building. The standard is managed and was created by the object management group [19], [25].

In this case we only show use case diagram. Use cases help us to understand and clarify the user's requirement for interactions with the system and reveal it most or all the functional requirements of the new system. [19], [26].

Architectural design are determines the software framework of a system to meet the specific requirements. This outline characterizes the real segments and the connection of those segments, yet it doesn't characterize the structure of every part. The outer interfaces and apparatuses utilized as a part of the venture can be dictated by the creator. Point by point outline are looks at the product segments characterized in the structural plan stage and creates a determination for how each part is executed [21]. Detailed Design included are designer data location source (folder name, set copy and description), temp data (file name, folder type, level), temp delete (file name, folder type, level), and data location destination (destination). Type Data are character and numeric, with length 1 until 200.

Coding is implements the detailed design specification [21]. Coding phases are receiving the design of the system documents, the work done is divided in to modules/units and actual coding is started. Since, in this stage the code is created so it is the fundamental concentration for the designer. This is the longest period of the programming advancement life cycle. For this situation, programming dialect with Microsoft Visual Fox Pro. Visual FoxPro began as an individual from the class of dialects normally alluded to as "xBase" dialects, which have linguistic structure in view of the dBase programming dialect.
Stages Testing: After the code is produced it is tried against the necessities to ensure that the item is really settled the necessities tended to and accumulated it amid the prerequisites stage. During this phase all types of functional testing like unit testing, integration testing, system testing, acceptance testing are done as well as non-functional testing are also done. Testing are determines whether the software meets the specified requirements and finds any errors present in the code [21]. Any software development process is divided into several logical stages that allow a software development company to organize its work efficiently in order to build a software product of the required functionality within a specific time frame and budget. All software projects go through the phases of requirements gathering, business analysis, system design, implementation, and quality assurance testing [27], [28]. In black-box, or functional testing, test conditions are developed on the basis of the program or system's functionality; that is, the tester requires information about the input data and observed output, but does not know how the program or system works. The tester focuses on testing the program's functionality against the specification. With discovery testing, the analyzer sees the program as a black box and is totally unconcerned with the inner structure of the program or framework [29].

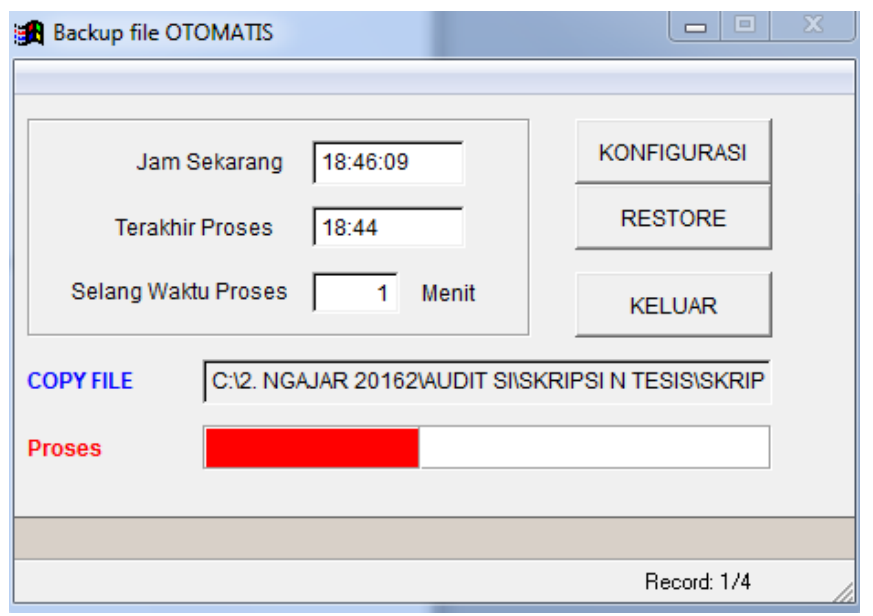

Fig.3. Backup Folder Processes

In figure 3 displays is where the backup progress shown in red running. Automatically incremental backup process will take place every minute. 


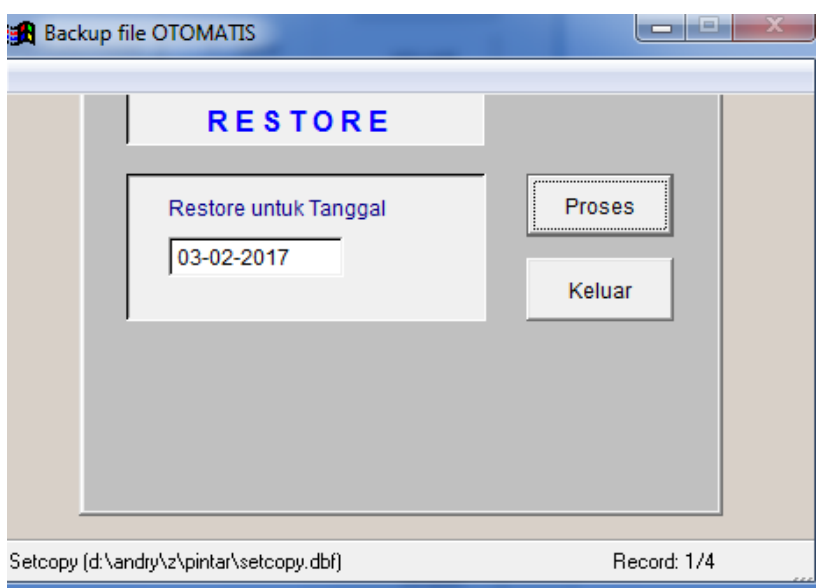

Fig.4. Restore Processes

In figure 4 displays is where the restore progress running. When will do restore then input date, month and year in text of application.

Execution stages are the stage that furnishes clients with the documentation and preparing necessity to utilize the framework viably. Information Conversion will just happen once, yet client documentation will be required. Sending of the item will be done, on the equipment that will be utilized as a part of generation (on live frameworks). Sending itself requires cautious arranging. Once the product is deployed, initial data will be populated, user training will happen. Stages support the framework data when the clients begins utilizing the created framework then the real issues comes up and should be fathomed every now and then. This procedure taken for the created item is known as support.

Universities rely on demand-based data systems as the lifeblood of e-learning operations, from student and faculty records to values and schedules to administrative applications and more. Loss of data can be expensive for educational institutions, such as loss of laptop or desktop data for staff and faculty or database servers containing records, exams. In general, while the term "disaster" typically generates an image of data and information loss from the network as a whole, in fact it is a loss of local data that is not only catastrophic but easily preventable.

\section{CONCLUSIONS}

The implementation of university information system backup and restore are successful automation to recover data damage or loss in the event of a disaster and recover a small portion of data that suffered damage or loss as a result of human error. Automation do not have a choice to the user backup time and backup data can only be done every 1 to 999 minute so that the same data you want to back up every minute, it puts a burden on the client computer hard drives in terms of memory usage.

Features of "SIPINTAR", includes Real-time backup that saves changes to your files every 1 minutes. It works for computers located on and off-university can access is very useful for computers that move around a lot like notebooks and tablets. Can select what files and folders want to backup on university computer. Can make changes to what is back up at any time through an easy to use program that runs on your computer.

The backup system will keep copies of old versions of files it has backed up. So can made a change to a file and wanted to revert to the version of the file as it was the previous week for example. Can restore files at any time without the assistance of technical support staff. Restoring files is accomplished through an easy to use point-and-click interface provided by SIPINTAR program installed on university computer.

\section{REFERENCES}

[1] Aldasouqi and A. Awajan, "Black Box Backup System," International Journal of Computer Science and Security, Volume 5, Issue 3, pp. 368375, 2011.

[2] E. Wijaya, Robet and Robin, "Perancangan Sistem Otomatisasi Backup Data Menggunakan File Transfer Protocol Berbasis Jaringan LAN (Studi Kasus Pada STMIK TIME Medan)," Jurnal TIMES, Vol. IV, No. 1, pp. 26-30, 2015, ISSN: 2337-3601.

[3] L. L. Hoong and G. Marthandan, "Critical Dimensions of Disaster Recovery Planning," International Journal of Business and Management, Vol. 9, No. 12, ISSN 1833-3850, E-ISSN 1833-8119, Published by Canadian Center of Science and Education, pp. 145-158, 2014.

[4] M. Gallangher, "Business Continuity Management - How to protect your company from danger. Retrieved, 2003. http://pqmonline.com/assets/files/lib/gallagher.pdf

[5] T. Virgona, "A Historical Study of the Human Aspects of Disaster Recovery," Paper presented at the Proceedings of the Northeast Business \& Economics Association, 2010.

[6] T. Singh, P. S. Sandhu and H. S. Bhatti, "Replication of Data in Database Systems for Backup and Failover - An Overview," International Journal of Computer and Communication Engineering, Vol. 2, No. 4, DOI: 10.7763/IJCCE.2013.V2.243, pp. 535-538, July 2013.

[7] S. Hettige and R. Haigh, "An integrated social response to disasters: the case of the Indian Ocean tsunami in Sri Lanka," Disaster Prevention and Management: An International Journal, Vol. 25, Issue 5, pp. 595-610, 2016. http://dx.doi.org/10.1108/DPM-11-2015-0263.

[8] S. M. Hawkins, D. C. Yen and D. C. Chou, "Disaster recovery planning: a strategy for data security, "Information Management \& Computer $\begin{array}{llllll}\text { Security Vol. } 8 \text { Issue } 5 & \text { pp. 222-230, } 2000 .\end{array}$ http://dx.doi.org/10.1108/09685220010353150.

[9] A. J. Karim, "Business Disaster Preparedness: An Empirical Study for measuring the Factors of Business Continuity to face Business Disaster," International Journal of Business and Social Science, Vol. 2, No. 18, pp. 183-192, October 2011

[10] M. Wallace, L. Webber, "The disaster recovery handbook," New York: American Management Association, 2004.

[11] O. O. Jethro, A. M. Grace, A. K. Thomas, " E-Learning and Its Effects on Teaching and Learning in a Global Age," International Journal of Academic Research in Business and Social Sciences, Vol. 2, N0.1, pp. 203-210, 2012.

[12] O. E. Temtamy, M. Majdalawieh and L. Pumphrey, "Assessing IT disaster recovery plans The case of publicly listed firms on Abu Dhabi/UAE security exchange," Information \& Computer Security, Vol. 24, Issue 5, pp. 514-533, 2016. http://dx.doi.org/10.1108/ICS-04-20160030 .

[13] J. F. Andry and J. Loisa, "The e-Commerce Potential for Home-Based Businesses: A Case Study," Jurnal Ilmiah FIFO P-ISSN 2085-4315 / EISSN 2502-8332, Volume VIII, No. 2, pp. 23-27, November 2016.

[14] G. S. Reddy, R. Srinivasu, S. R. Rikkula and V.S. Rao, "Management Information System to Help Managers for Providing Decision Making in an Organization," International Journal of Reviews in Computing, pp. 16, 2009.

[15] M. C. Shibin Tad and K. A. Janardhanan, "The Role of Information System in Disaster Management," International Journal of Management 
and Social Sciences Research (IJMSSR) ISSN: 2319-4421, Volume 3, No. 1, January 2014.

[16] P. Isaias and T. Issa, High Level Models and Methodologies for Information Systems, () Springer Science+Business Media New York 2015, DOI 10.1007/978-1-4614-9254-2_2.

[17] S. Balaji, M. Murugaiyan, "Waterfall vs. V-Model vs. Agile: A comparative study on SDLC," International Journal of Information Technology and Business Management 2(1), 26-30, 2012.

[18] M. Shaw, "What Makes Good Research in Software Engineering?," International Journal of Software Tools for Technology Transfer, vol. 4, no. 1, pp. 1-7, 2002.

[19] J. F. Andry, H. Agung and Y. Erlyana, "Management Information System for Order Fulfillment: A Case Study," Proceeding of 9th International Seminar on Industrial Engineering and Management, ISSN : 1978-774X, September 2016.

[20] Y. Bassil, "A Simulation Model for The Waterfall Software Development Life Cycle," International Journal of Engineering \& Technology, vol. 2, no. 5, 2012.

[21] N. M. A. Munassar and A. Govardhan, "A Comparison Between Five Models Of Software Engineering, "International Journal of Computer Science Issues, ISSN (Online): 1694-0814, Vol. 7, Issue 5, pp. 94-101, September 2010.

[22] J. F. Andry, H. Agung and Y. Erlyana, "Management Information System for Order Fulfillment: A Case Study," Proceeding of 9th
International Seminar on Industrial Engineering and Management, ISSN : 1978-774X, September 2016.

[23] A. Dennis, B. H. Wixom, Roth and M. Roberta, "System Analysis and Design, fifth edition," John Wiley \& Sons, Inc, 2012.

[24] A. Jakimi and M. E. Koutbi, "An Object-Oriented Approach to UML Scenarios Engineering and Code Generation," International Journal of Computer Theory and Engineering, vol. 1, no. 1, pp. 35-41, 2009.

[25] Q. Siddique, "Unified Modeling Language to Object Oriented Software Development," International Journal of Innovation, Management and Technology, vol. 1, no. 3, pp. 264-268, 2010.

[26] A. Dennis, B. H. Wixom, Roth and M. Roberta, "System Analysis and Design, fifth edition," John Wiley \& Sons, Inc, 2012.

[27] A. Mishra and D. Dubey, "A Comparative Study of Different Software Development Life Cycle Models in Different Scenarios," International Journal of Advance Research in Computer Science and Management Studies, ISSN: 2321-7782 (Online), Volume 1, Issue 5, pp. 64-69, October 2013

[28] R. Klopper, S. Gruner and D. Kourie, "Assessment of a framework to compare software development methodologies," Proceedings of the 2007 Annual Research Conference of the South African Institute of Computer Scientists and Information Technologists on IT Research in Developing Countries, pp. 56-65, 2007. Doi: 10.1145/1292491.1292498.

[29] W. E. Lewis, "Software testing and continuous quality improvement," third edition, Auerbach Publications, Taylor \& Francis Group, 6000 Broken Sound Parkway NW, Suite 300 Boca Rat, 2009. 